\title{
Hopes and Feurs for US Science Policy
}

by our Washington Correspondent

THIS month marks the end of an era in US science policy and the beginning of another. That, at least, is the theory, for on July 1 the Office of Science and Technology was formally abolished and its functions transferred from the White House to Dr H. Guyford Stever, Director of the National Science Foundation. The machinery established by Presidents Eisenhower and Kennedy, which gave science a place in the highest corridors of power in the United States, has thus been dismantled and the head of a tiny government agency-described by $\mathrm{Dr}$ Stever himself as "the junior partner in science"-has been given the task of watching over his big brothers in the rest of the federal establishment.

But is the new machinery really so different? Last week the House Committee on Science and Astronautics held two days of hearings to discover how the new science policy apparatus may work in practice, and it became clear that in the six months which elapsed between OST's sentence and execution, new arrangements evolved which, in a few key respects, bear a striking resemblance to the old. Nevertheless, suspicions that science has been downgraded in the federal government have not been entirely allayed.

When the new arrangements were announced in January, there was strong criticism of the fact that Dr Stever would be Science Adviser not to the President, but to the President's assistants. Unlike Dr Edward E. David who, until he resigned in January, bore the title Science Adviser to the President, Dr Stever's official title is Science Adviser, but to nobody in particular. The original idea was that his advice would go chiefly to Dr George Shultz, Secretary of the Treasury and President Nixon's special assistant on economic affairs. But last week Dr Stever made public a letter he received from the President on July 1, in which Nixon formally designated him as "my Science Adviser".

It may be merely a semantic difference, but members of the committee were eager to know the significance. Stever said, in reply to a question from Mr Ken Hechler of West Virginia, that the letter clarifies his responsibilities "quite a bit", and that he feels he "can go to the President on a matter of urgency". He later said, however, that he would expect to take Shultz with him on such a visit. How many times has Stever met the President? Three times since January, once for a lengthy meeting on international scientific relations, and two "much shorter meetings on other matters", Stever replied, and added that he has had "more frequent conversations with $\mathrm{Mr}$ Ash (Director of the Office of Management and Budget) and Mr Shultz".

Three visits to the President in six months does not suggest a close relationship between Mr Nixon and his Science Adviser, but as one former OST staff member pointed out last week, "none of the committee members asked how many times Dr Edward David saw the President". He suggested that Stever's record of visits is not bad in comparison, but that a more important question is whether or not advice reaches the President through channels other than personal representation. One of the hallmarks of the Haldeman-Ehrlichman era at the White House, he said, was that advice, memoranda and reports from the OST were ignored or buried and seldom reached the President's attention. The post-Watergate White House may be more receptive to scientific advice.

Perhaps more important than the number of audiences Mr Nixon grants to his Science Adviser is the working relationships between science policy. makers and other elements of the White House, particularly the Office of Management and Budget. Since it involves the lifeblood of the federal agencies, preparation of the budget estimates of the Administration is the most important annual exercise in the executive branch of the government, and the OST's chief influence came from dayto-day workings with officials of the OMB. Have those contacts been main. tained now that science policy advice has been shifted from the White House?

Dr Stever announced earlier this month that he has established a small Science and Technology Policy Office (STPO) to assist him in his new role (see Nature, 244, 5; 1973), and it is this office which will carry out most of the work with OMB. It so happens that the ten staff members, including secretaries, so far appointed to STPO are all former staff members of OST, and they are also located in the old OST offices in the Executive Office Building. At the working level, the new arrangement thus looks very much like a slimmed down version of the old one.

One point on which committee mem. bers expressed considerable reservation is that Dr Stever must wear two very different hats in his duties as Director of the National Science Foundation and as Science Adviser. He may, for example, face a conflict of interest in advising OMB how to divide the pie for science and technology among the various agencies of the federal government. Stever agreed that his dual responsibility is a potential problem, but said several times during his testimony that STPO has been deliberately set up outside the mainstream of usual NSF activities to provide an independent source of advice to him.

In April this year Dr Stever established in the National Science Foundation an Energy Research and Development Task Force, under the direction of Dr Paul F. Donovan, to provide advice to him on energy policy. But, with the appointment of $\mathrm{Mr}$ John Love as President Nixon's special adviser on energy policy, and the establishment of the Energy Policy Office in the White House (see Nature, 244, $4 ;$ 1973), the functions of the NSF's task force have to some extent been overtaken. Nevertheless, Dr Stever said last week that "one of the principal objectives" of the task force will be "to contribute to the formula. tion of the 1975 budget". It did not escape the committee's attention that, after abolishing the Office of Science and Technology, President Nixon has established the Office of Energy Policy in the White House to carry on one of the OST's functions.

It thus seems that the new science policy machinery evolving under the Director of the National Science Foundation is, in some respects, not very different from the old regime. But there are, however, two important changes to be noted.

The first is that the President's Science Advisory Committee, which provided advice to the White House, has not been reinstated. Dr Stever said last week that he has not yet made up his mind about how best to seek the views of the scientific community, but stated his "personal philosophy that advisory groups are best used on an ad hoc basis, selected for a particular problem, and kept in operation only for the life of the problem". The other change is that Dr Stever has no brief for giving advice on defence research and development.

It so happens, however, that the Department of Defense receives about half of all federal research and development funds. 